\title{
YAmANOUChI, Yoshiko: On Deviated Food Habit in Infancy Report 2. Children's Attitude to Carrot
}

\section{小兒性食性異常について}

第 2 報 小児の人参に対する態度 広鳥女子短期大学

山内 美 子

著者は『いわゆる 偏食の実態調査及び 対策 の指針探求』(1) 中で「人参を嫌了理由」人 参を嫌 5 年令的推移」を発表したが，本報で は人参のみの単材料で料理をした物 8 種類を 普通児と盲児の男女に試食させて, 男女間, 家庭の職業間，両者間に差異があるか否かを みると同時に，嫌食に対する一般対策をつか もらと試みた。

\section{調查対象涉びに調查方法}

昭和 31 年 $5 \sim 7$ 月に広島市立 宇品小学校 6 年生男女 30 名, 広島県立盲学校小学部 $5 \cdot 6$ 年 生男女 27 名に昼食直前注試食させた（両者間 の平均年令は大体同じ).

人参は大 (短冊切り …横 $2 \mathrm{~cm}$, 縦 $4 \mathrm{~cm}$, 厚 さ $0.5 \mathrm{~cm})$, 小 (みぢん切り)に切つた。

人参の料理は姿のわかる物…辛煮(亀甲万徆 油 $11 \%$ ), 甘著（砂糖 $5 \%$, 塩 $1.2 \%$ ), 眽の物 (3杯酢), カレ一惹（カレー粉 $1.3 \%$, 塩 1.2 $\%$ ）, 葛煮（葛 $2 \%$, 俆油 6\%, 砂糖 $2 \%$ )。姿 のわからない物…ふふらら, 白和兄, 蒸しパン (小切りの人参を芋餾へ混じた物, 小切りの人 参をパンの表面の中央へ䈈めこんだ物)。

試食の前日に盲児と小茶話会を開いて踈通 を計つたが，普通児はこの労をとらなかつた。 理由は盲児が疑惑を懐いて協力してくれない と困ると思つたからである.

試食の直前に 料理法の説明を両者に簡単に
した。食前と食後の感想を普通児には調查用 紙へ記入させ，盲児は個人聴取した。

学内の教職員, 副手, 事務職員の男女 15 名 づょに人参の切り方について大小何れがよい か，個人面接をした。

\section{調 查成績}

(第1 5 図の No. 4 まで 90\% の信頼度, 第 5 図の No. 5 は $60 \%$ の信頼度である).

（I）人参料理を全体的（短冊切りとみだ ん切り，及び男女の平均飞みると第 1 図 No. 1〜5のよラになる. No. 1 図の「好む」物は 天ぷらで殆どの小児に好まれている。耐児間 には有意の差は認め難い。白和兄は普通児が 特に好んでいる。No.2 図の「轱う」のは普通 児が多い。料理法はカレ一惹, 辛煮, 甘募, 白和えである. No. 3 図の「普通」は盲児が多 く, 白和兄, 辛募, カレー惹, 甘煮を好悪感 なく食へている.No.4 図は「好む」と「普通」 を合計したのであるが, 盲児が, カレー煮, 辛煮, 甘煮, 白和光をよく食べることになる。

尚，好 (好む十普通) 恶の差を No. 5 図でみ ると, 盲児は天ぷら, カレ一煮, 白和克, 辛 煮, 甘煮を文句なしに食べるに反し, 普通児 は, 天ぷら, 白和克以外は大体燃つている傾 向であるが, カレ一煮, 酢の物は特に婔惡し ている。普通児と盲児間では盲児がカレー煮， 白和克, 辛煮, 甘煮をよく食べるようである。

（II）切り方について (第 2 図, No.1〜2) 
A. 好まれる切り方（No. 1 図）

普通男児のみ 過半数が美味しく食すようで ある。その男児の傾向は大 5 ：小 1 である。

1）男女差‥普通児では男児がカレ一煮, 辛 煮の大切り, 葛煮の大切り, 小切りを好んで いる・甘煮は $60 \%$ の信頼度でも 差は認め 難 い. 盲児は $60 \%$ の信頼度でも差は認め難い。

2）普通児と盲児間…男児間では普通児が小 切りの白和え, 葛煮を好み, 他は $60 \%$ の信賴 度でも差は認め難い。女児間では $60 \%$ の信賴 度でも差は認め難い。

3）食前の感じと味の好悪は同傾向である.

B. 婎瑟される切り方 (No.2 図)

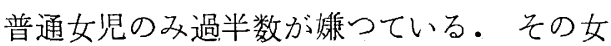
児の傾向は大 4 ：小 1 である。

1）男女差…普通児では女児が辛煮, 葛惹, カレー煮の大小を閣わず嫝つている．天ぷら の大切り，甘煮の小切りは $60 \%$ の信頼度でも 差は認め難い。盲児は $60 \%$ の信頼度でも差は 認め難い。

2）普通児と盲児間の差…男児間では差は認 め難い。女児間は普通児が辛煮，カレ一徭の 大切りを轺い，酢の物，甘煮の小切りは $60 \%$ の信頼度でも差は認如難い。

3）食前の感じと味の嫌悪は同傾向である.

C. 积悪感なく食べる切り方（No.3 図）

No. 1〜2 図で有意の差の認められた料理の 「好き」と「普通」を加えてみると，各料理と も普通女児以外は $60 \%$ の信頼度でも差は認め 難い程, 嫙㗚感なく食べる.

（四）切り方の大小による好悪差（第 3 図， No. $1 \sim 2$ )

A. 大切りについての好瑟差 (No.1 図)

天ふらら4 者に好をれている。その他の料 理は普通女子に嫌われ，他の 3 者の好悪美は 認め難い. 7 種の料理の平均值は普通男児が 好み，普通女児が頛つている。盲男女は $60 \%$ の信頼度でも差は認好難い。

B. 小切りについての好瑟差 (No.2 図) 天ぷらは普通男児，盲男女が特に抺さ汉
し，普通女児は $60 \%$ の信頼度で差が認められ る. 更に同女児は白和え，甘煮も好んでいる。 他の 3 者間では $60 \%$ の信頼度で, 普通男児が 葛煮, 白和学を好み，盲男児は葛煮を啛つて いる. 平均は大切りと同調である.

（IV）食前の感じ（第 4 図）

天ぷらは 4 者が好感を懐いている. 辛煮, 吉 野煮, 甘煮, カレー煮, 酢の物は普通女児が 悪感情を懷いている.この 5 種を第 2 図 No. 2 を参照すれば何れも高率を示している。

（V）職業別についての媒悪状態（第 5 図, No. 1 4)

精神労働と肉体労働に大別した。精神労働 忪務員, 教員, 事務員, 商業の中菓子販売 店をし, 肉体労働は失業対策, 工, 農, 商業 の中自転車修理, 父死亡冊無職をした。少人 数のため男女に分けなかつた。精神労働者は 普通児 13 人で $43.3 \%$ ，盲児 8 人で $29.6 \%$ ，肉 体労働者は普通児 17 人で $56.7 \%$ ，盲児 19 人 で 70.4\% となる。盲児間は有意の差が認めら れる。

1）全体的にみると，精神労働者の小児が嫌 万傾向である. 特に大切り (No. 1 2) の辛煮 を両者が，小切り（No.3〜4）は特に普通児が 辛煮を，盲児は白和えを期つている。

2) 料理別(No.5) にみるため第 1 図 No. 1 〜4 から稼悪している物を取り出してみた。

甘煮…精神労㗢者の普通児が大切りを煤 $っ$. 辛煮…精神労働者の普通児は大小の切り方 を，同職の盲児は大切りを稼う。

カレー煮…精神学働者の普通児が嫌 5 傾向. 白和之…4 者とも50\% 以下のため諭を要せ ず.

\section{考案}

1）人参は多くの小児が㮐つているが，調味 料や調味法，切り方を变えれば殆どの小児が 食べる事が判つた。1 報で「料理法を变えれ ば食べられるかぞうか判らない」13.9\%，「絶 対に食べない」が $17.4 \%$ いたが，本実験によ 
り，踭食品は天ぷら，和え物（サラダ，味噌 和え, 胡麻和觉, 白和え等）にして, その物 を直接舌に触れさせない事と，旬を消し味を 変えるために 小さく切つて 調味料を充分渗透 させる事である，又間食として蒸しぱんの中 に微塵切り, 又は裏ごしにして入れると食べ 易くなる。

2）普通男児が大切りを，同女児が小切りを 好む傾向について推察した. 小学 6 年生とい えば心身共に 女児が男児を凌駕する時期であ る・そこで著者は成人男女に「人参はどんな に切つたのがよいか」と個人面接をして縓め ると第 1 表の如々，成人の多くは大炀りを好*
肉体学働家庭が多いからで人参の色，形態が みえないからではないと思5。家庭の職業， 旬，味が影響を及ぼすものと思われる。

4）肉体学衝者の小児が辛煮を好むのは親の 嘴好に影響されていると思われる。

5）食品に対する心理的効果は，見た感じが 過去に経験した舌ざわり，歯ごたえ，風味等 に条件反射的に作用するものと思われる。故 に配色, 形態, 季節感, 盛付及食器にも意を 配れば眼を楽しませるのみでなく，不当な緊 張，抵抗がなくなるから，愉快に食事が出来 ると同時に 各種の栄養素る攝取されるので, 心身の保健，衛生上好ましいと思われる。

第 1 表 成人の人参の奶り方に対する態度（信頼度 $90 \%$ ）

\begin{tabular}{|c|c|c|c|c|c|c|c|c|}
\hline & 理 & 男 & 子 & 女 & 子 & \multicolumn{2}{|c|}{ 計 } & \\
\hline & 小切りは人参その物の味がわがらない & 9人 & $60.0 \%$ & 8人 & $53.4 \%$ & 17人 & $56.8 \%$ & \\
\hline 大 & \multirow{2}{*}{$\begin{array}{l}\text { 小さく切ろのは面倒惊ので大切りにして䲵达光 } \\
\text { 小さいのは舌ざわりが悪い }\end{array}$} & - & - & 2 & 13.2 & 2 & 6.7 & \\
\hline 切 & & 1 & 6.7 & - & - & 1 & 3.3 & \\
\hline v & 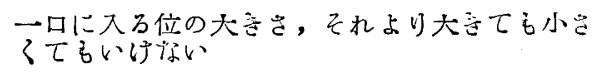 & 1 & 6.7 & - & - & 1 & 3.3 & \\
\hline$s^{5}$ & 小さいのは菌こたえがない & 1 & 6.7 & - & - & 1 & 3.3 & \\
\hline よ & \multirow{2}{*}{$\begin{array}{l}\text { 小さいのを食べたことがはいからわからない } \\
\text { 小さいのは盛り付けが難しい }\end{array}$} & 1 & 6.7 & - & - & 1 & 3.3 & \\
\hline \multirow[t]{2}{*}{ い } & & - & - & 1 & 6.7 & 1 & 3.3 & \\
\hline & 計 & 13 & 86.8 & 11 & 73.3 & 24 & 80.0 & \\
\hline $\begin{array}{l}\text { 小 } \\
\text { 切 }\end{array}$ & \multirow{2}{*}{ 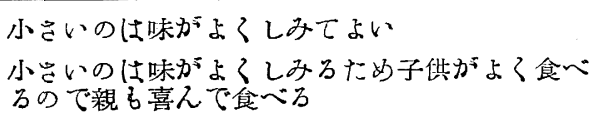 } & 2 & 13.2 & 3 & 20.0 & 5 & 16.7 & \\
\hline 证 & & - & - & 1 & 6.7 & 1 & 3.3 & \\
\hline $\begin{array}{c}5 \\
6 \\
6\end{array}$ & 計 & 2 & 13.2 & 4 & 26.7 & 6 & 20.0 & \\
\hline & 合 & 15 & 100.0 & 15 & 170.0 & 30 & 100.0 & \\
\hline
\end{tabular}

*んでいる。これに則れば男児の搘好が女児よ り早く成人に似る傾向がある。即ち男児の方 が生活場面に対する適応性が早期に表われる ようである．普通児と盲児とでは盲児の方が 早いようである. 又女児の天ら゚らより考察さ れることは「美味」と感じた物は大切りを好 むともいえるのではないだろうか。

3）肉体学働者の小児が大切りを好むのは生 活場面に適応せざるを得なくなるのではない だううか，又盲児が各料理をよく食べるのは

\section{要 約}

普通児と盲児に大小に切つた八参の単材料 料理各種を試食させて㓷食に対する対策を具 体的に探究した。(1) 両者の男女が高率で好む 物は天ふららで，嫌う物は認め難い。(2) 盲女児 は文句なく食べる。同男児は葛煮を特に褄 弓。 普通男児は一般に好感的に食べる。同女児は 天ふらら，白和え以外は頝 5 . (3) 切り方は普通 男児は大 5 ：小 1 で好み，同女児は大 4 ：小 1 で粠 5。盲男女児は拘泥しない。(4) 食前後 
感は 4 者とも同傾向を示す．（5) 職業別にみる と精神労働者の小児が 肉体労働者の小児より 嫌 5 傾向が大である. (6) 成人男女が大切りを 好むことから推察すると，普通女児は普通男 児や盲男女児よりも，又精神学働者の小児は 肉体労動者の小児よりも生活場面に対する適 応性が遅いよ5に思われる。(7) 食前感は条件 反射的に嗜好的価值を左右する重要な因子と
なるから, 配色, 季節感, 形態, 盛付及び食 器等には配慮することが肝要と思われる。 擱篗にのぞみ, 東京大学名誉教授福田邦三博 士の御指導と御校閲を深謝すると共に, 調查の 手层いをしてくれた広島女子短大生島淑子, 結 城当子に敬意を表する.

\section{引用文献}

(1) 山内美子： 民族䲞生, 21 卷 3,4 둑, 


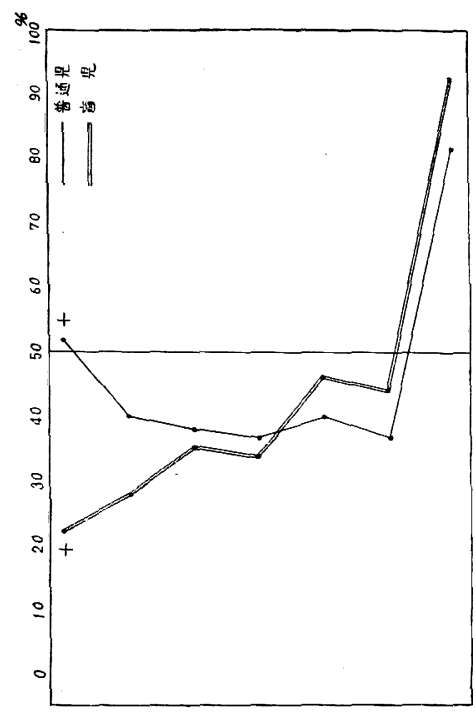

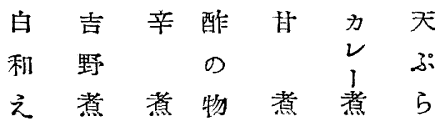

No. 1 好吉状態（+は90\%の有澺の差を示す）

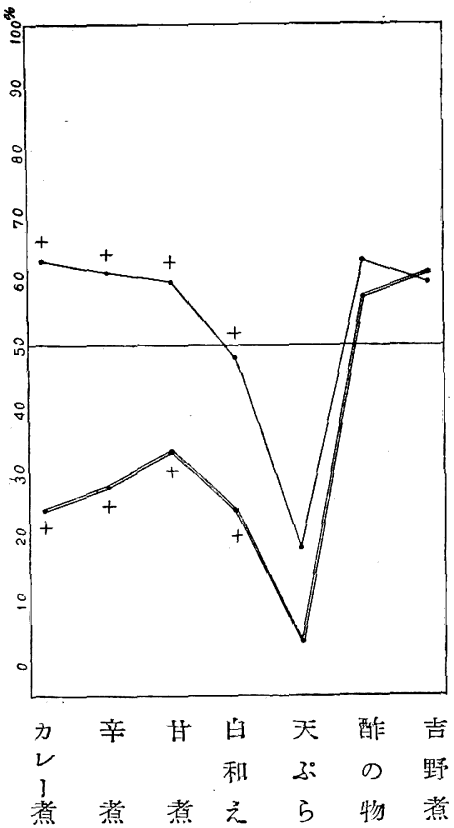

No. 2 娽 う 状 態

第1図到通兒々盲兒の好悪

(短册切りとみぢん切切及び男女の本均)

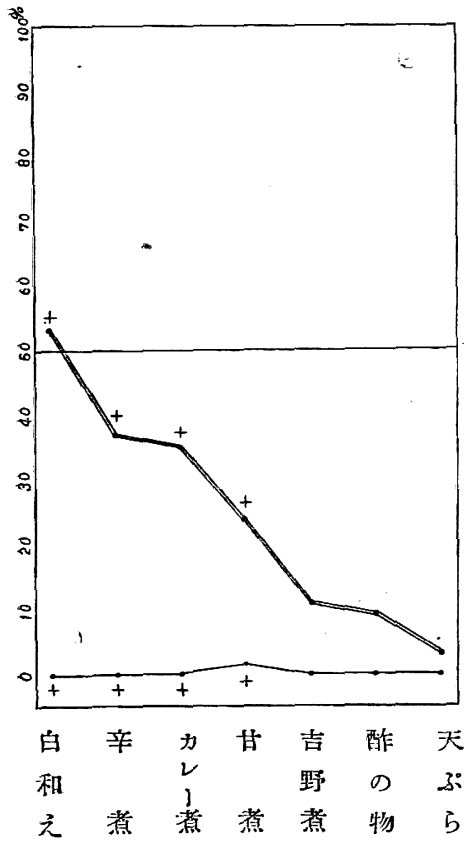

No. 3 普通の状態
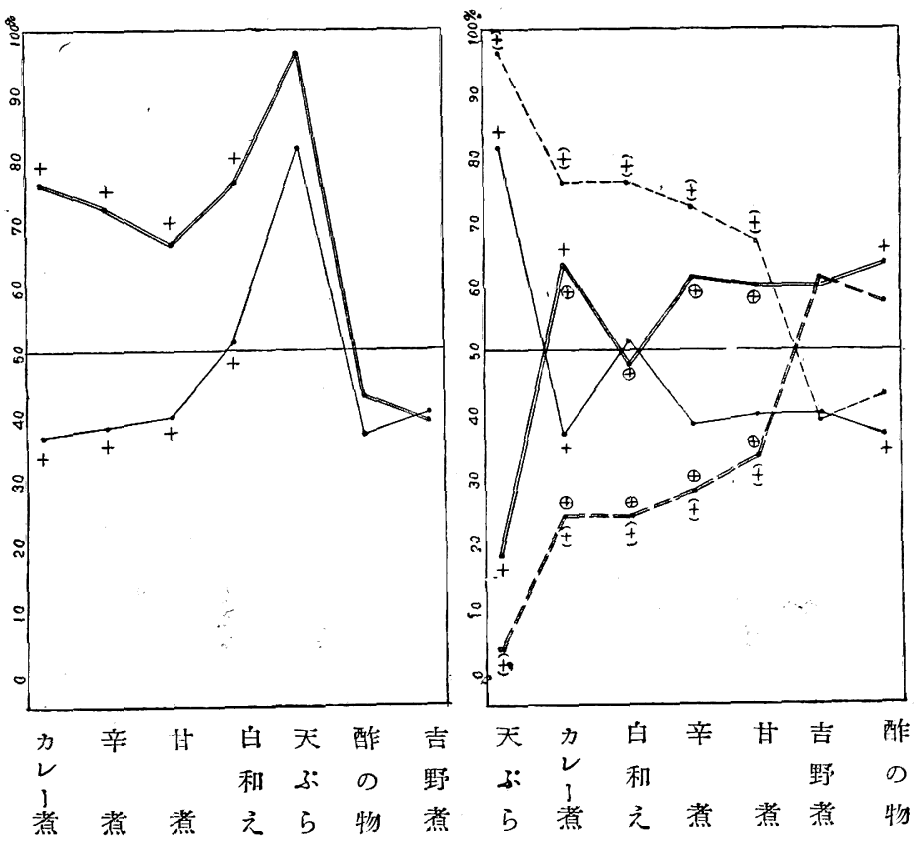

第 1 図

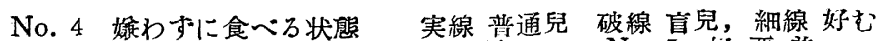

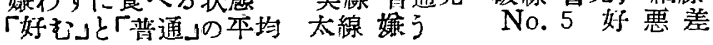




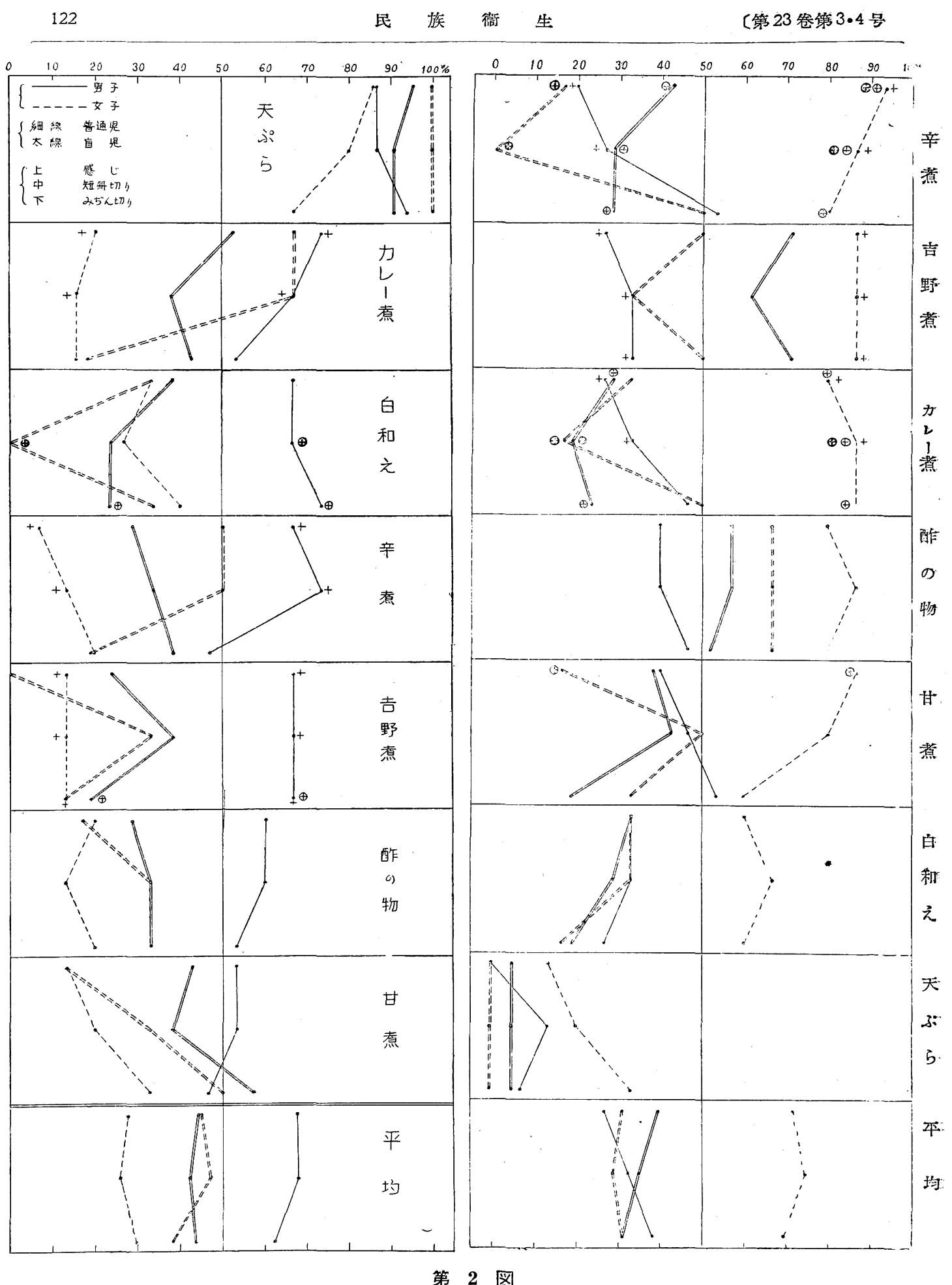

No. 1 好まれる切り方（信頝度 90\%）

No. 2 婙われる切り方 


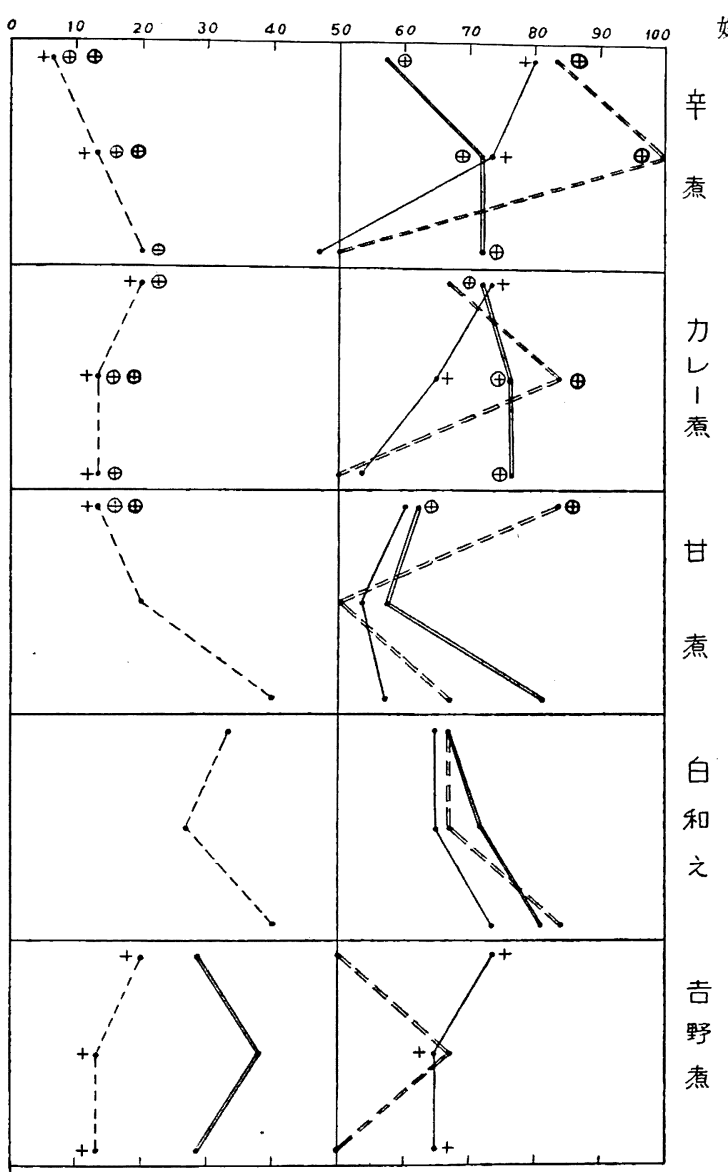

第 2 図

No. 3 好悪感なく食べろ切叮方

(「好む」と「葿通」の本均)

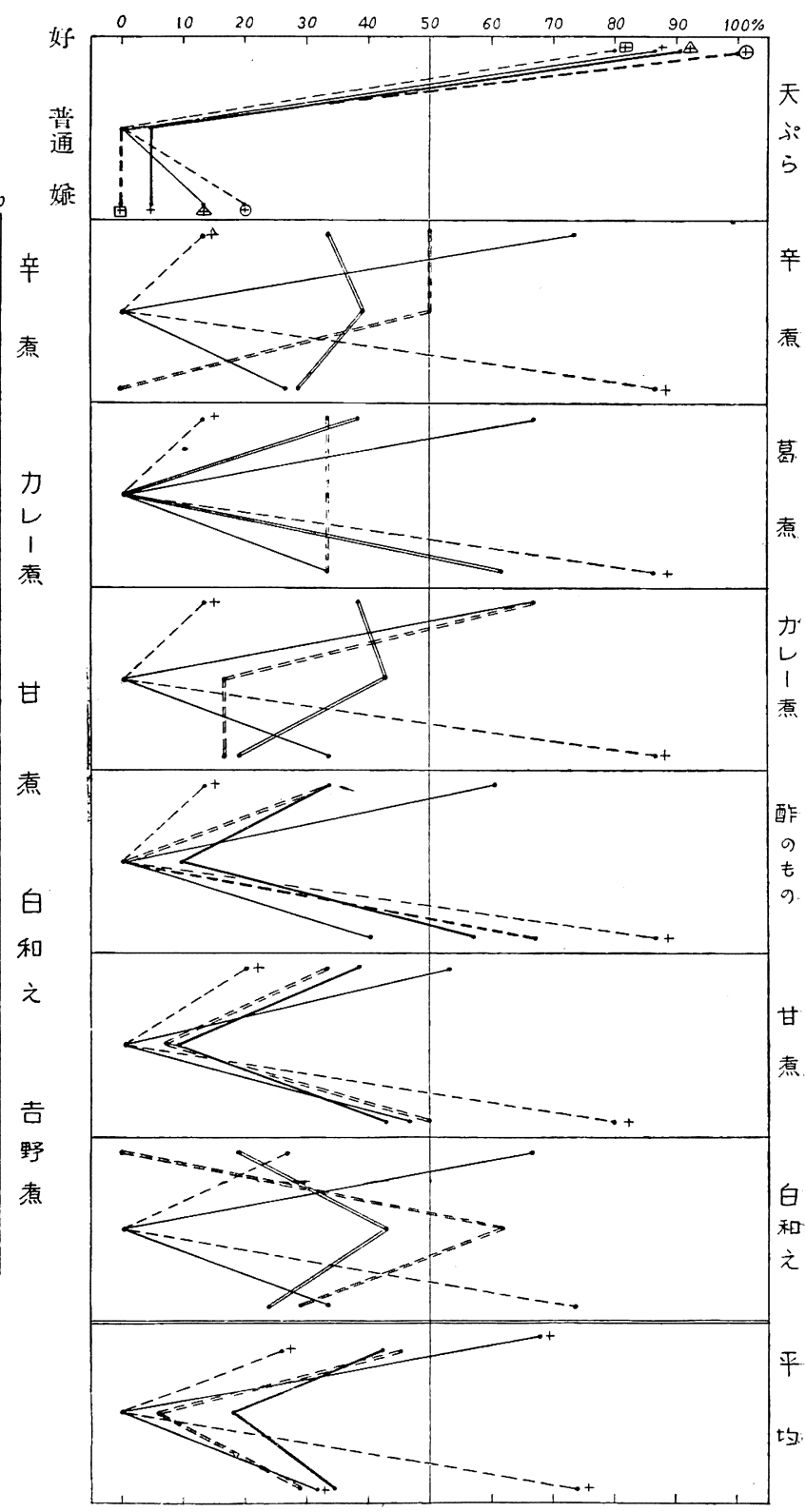

第 3 図

No. 1 短册切りについての好悪差（信賴度 90\%） 


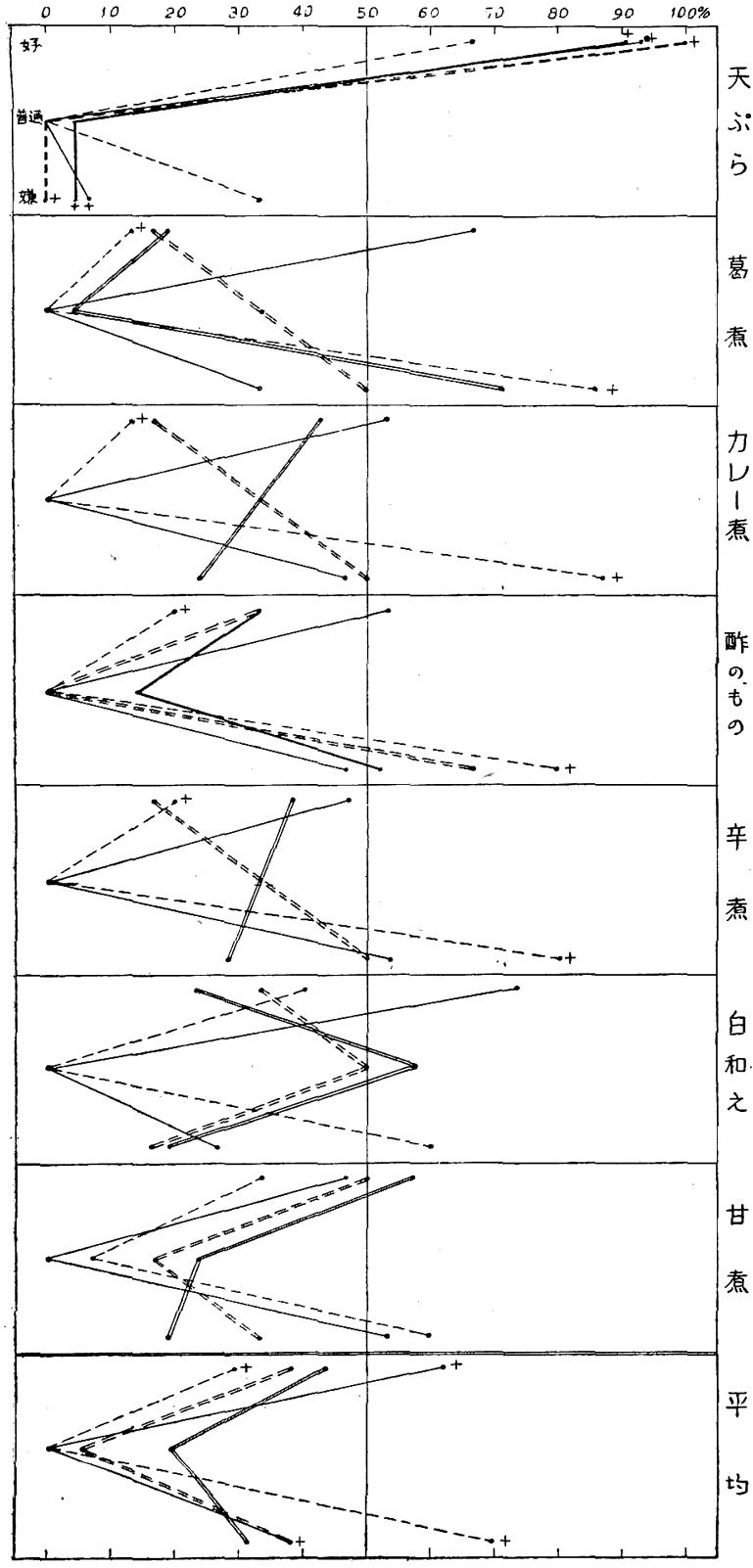

第 3 図

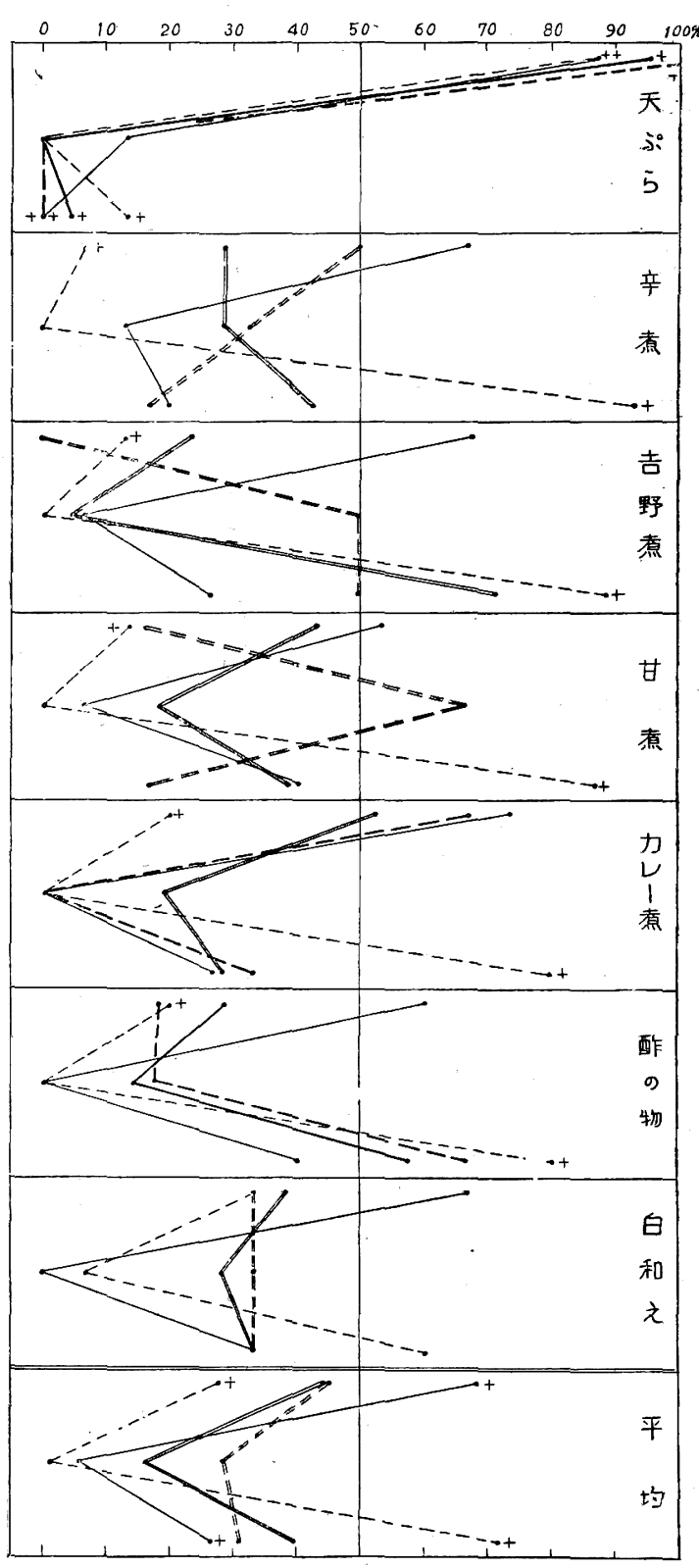

第4図 食へろ前の感し（信賴度 90\%）

No. 2 みぢん切りについての好悪差 


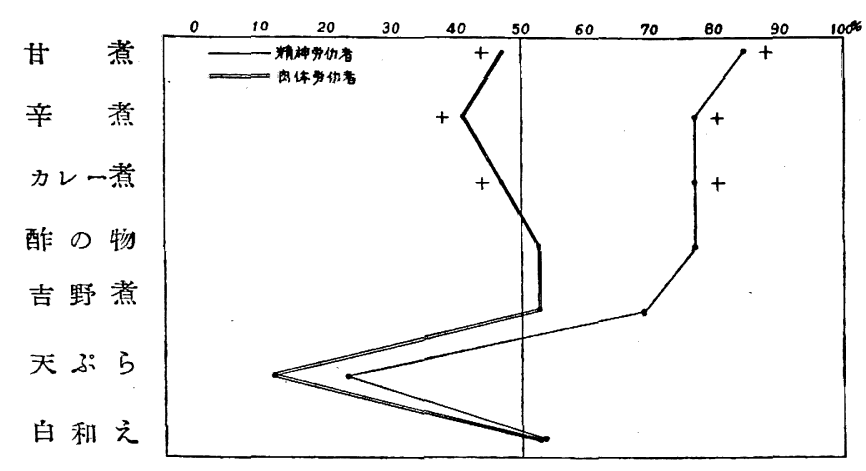

第5図 職業別について（婔悪するるの）

No. 1 短册切比(曹通兒) (信賴㡲 $90 \%$ )
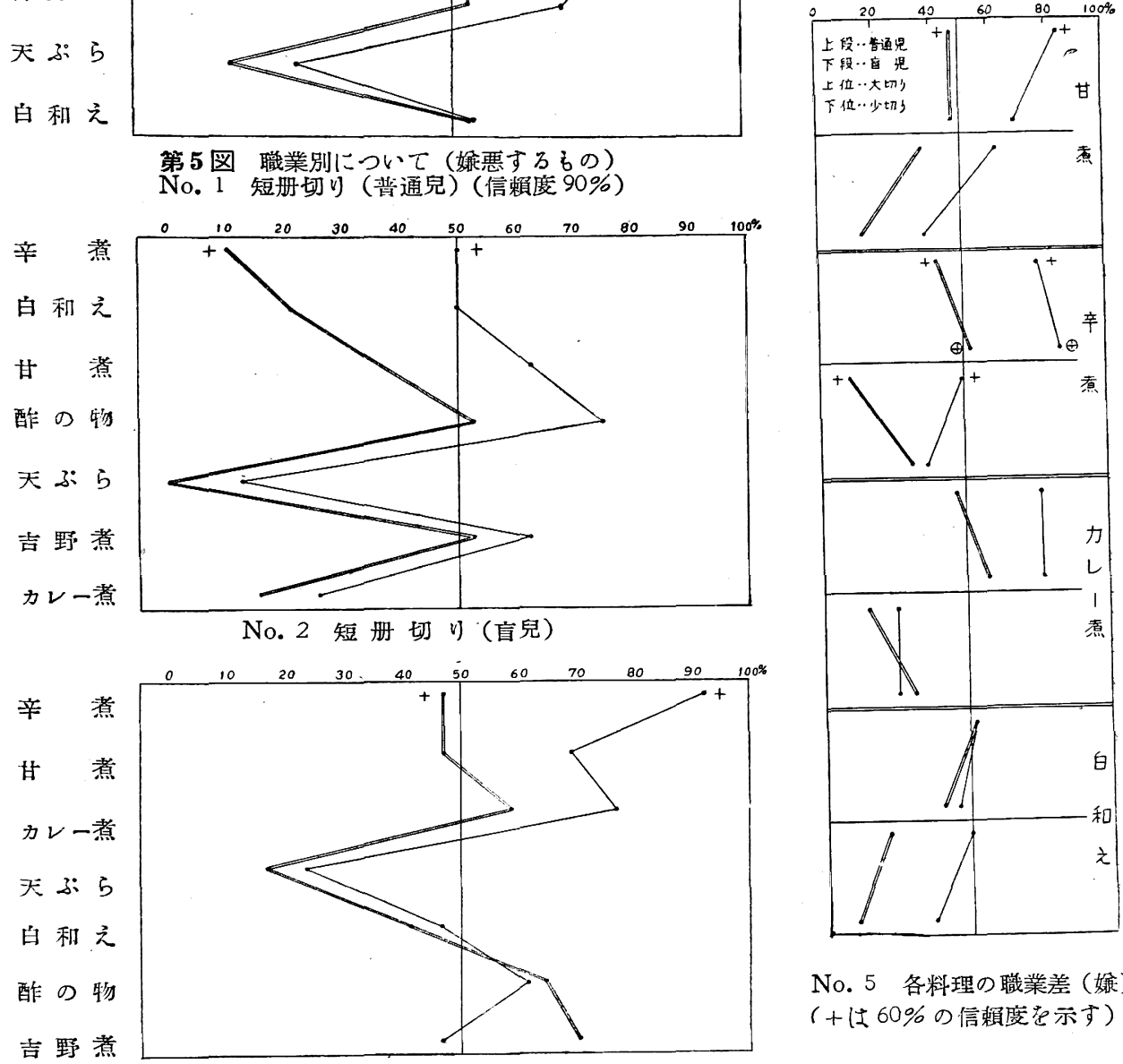

No. 5 各料理の職業差 (様): (+は60\%の信賴度を示す）

No. 3 み 5 ん切り（背通兒）

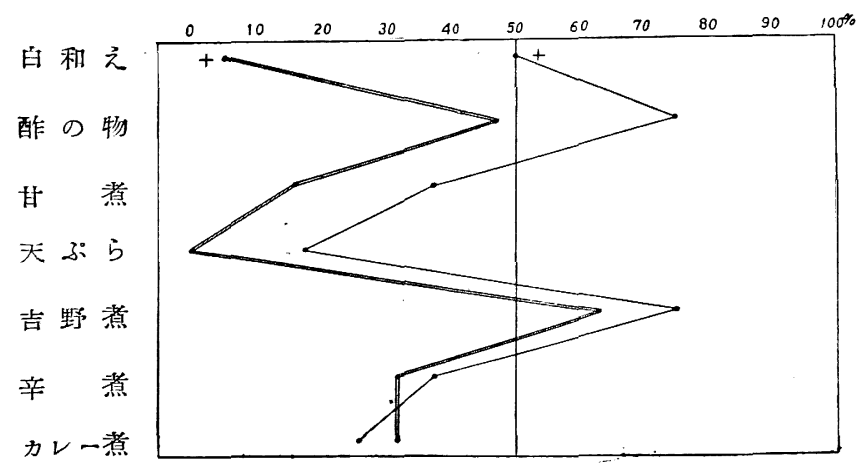

No. 4 みぢて切り（直兒） 


\section{ON DEVIATED FOOD HABIT IN INFANCY \\ Report 2. Children's Attitude to Carrot.}

By

\section{Y. YAMANOUCHI (Miss)}

Thirty children of normal vision, male and female, from the 6 th grade and 27 blind children from the 5 th and 6 th grades were examined, immediately prior to lunch, with carrot dishes of different cutting, cooking and dressing.

Although carrot is disliked by most children, the present study showed that they take some kinds of carrot dishes quite willingly. For instance, tempură is liked by most children.

(From the Hiroshima Prefectural Junior College)

\section{POSTURAL BLOOD PRESSURE REFLEX OF PULMONARY TUBERCULOSIS PATIENTS \\ By}

M. SUGANO, S. OGIHARA and T. YANO

The postural blood pressure reflex was examined on fifty patients of pulmonary tuberculosis, 32 males and 18 females, 21 to 57 years of age, now being taken care of in a sanatorium. In the present study, mainly the fluctuations of the maximum blood pressure points were analyzed.

In summary, it was fou $\mathrm{d}$ that the brachial blood pressure declined in 22 patients $(44 \%)$ after the posture change from sitting to lying, and in case of posture change from lying to sitting, 33 patients $(66 \%)$ showed insufficent restoration of the blood pressure. In view of these facts, it is supposed that the regulatory ability of the blood pressure in pulmonary tuberculosis patients is insufficent, compared with that of healthy subjects. The fluctuation and restoration curves of the blood p:essure, to some degree, seems to be determined by age, and generally speaking, the older the patients are, the more likely they are to show an abnormal fluctuation of the blood pressure. the

From the Derartment of Public Health, School of Medicine, Gumma University, Maebashi. 